\title{
Urinary Tract Infection and Pregnancy
}

\author{
Mohammed Nizar Battikhi* \\ Battikhi central laboratory, Ibn Khaldon street ,Amman Jordan
}

Received: December 22, 2017; Published: January 19, 2018

*Corresponding author: Dr. Mohammed Nizar Battikhi, 1017-1645 De Maisonneuve 0, Montreal, Quebec, H3H2N3 Canada, Tel: 514-933-5613; Email: m_nizar11@hotmail.ca

\section{Editorial}

A urinary tract infection (UTI) is an infection in any part of your urinary system, kidneys, ureters, bladder and urethra. Most infections involve the lower urinary tract the bladder and the urethra. Urinary tract infections don't always cause signs and symptoms, but when they do they may include. A strong, persistent urge to urinate, burning sensation when urinating passing frequent, small amounts of urine .urine that appears cloudy, urine that appears red, bright pink or cola-colored-a sign of blood in the urine, strong-smelling urine, pelvic pain, in women- especially in the center of the pelvis and around the area of the pubic bone. Urinary tract infections typically occur when bacteria enter the urinary tract through the urethra and begin to multiply in the bladder. Although the urinary system is designed to keep out such microscopic invaders, these defenses sometimes fail. When that happens, bacteria may take hold and grow into a full-blown infection in the urinary tract.

The most common UTIs occur mainly in women and affect the bladder and urethra [1]. Gram negative bacteria is the leading cause of urinary tract infection particularly UTIs [2,3] where over eight million cases of UTI reported annually and more than one million were hospitalize for an over-all annual cost of more than $\$ 1$ billion $[4,5]$ and responsible for $35 \%$ of the cases where bacteraemia is the most common therefore, proper investigation and correct prescription of antibiotics are needed to prevent serious life threatening condition and morbidity rate in pregnant women [3]. In has been reported that most of the uropathogens were same as over the years but the antibiotic resistance pattern was varied [6].

Diagnosis of UTI causing organism is the major work load in medical lab $\urcorner$ oratories where Escherichia coli reveal the highest predominate rate although, other reports showed that the causative organism of UTI is changing over the year and other microorganism were responsible for infection $[7,8]$. Occurrence of Urinary tract infection (UTI) is a common bacterial infection found in both genders which affect the different parts of the urinary tract and women are more susceptible due to short urethra and its anatomical proximity to the anal orifice $[9,10]$.

Invasion of lower and upper urinary tract by microorganism is one of the most commons cause for uroginital infection in general and UTI infection in particular which has been reported as the most common bacterial infections during pregnancy [11]. UTI is defined as the presence of at least 100,000 organisms per milliliter of urine in an asymptomatic patient, or as more than 100 organisms $/ \mathrm{ml}$. of urine with accompanying pyuria ( $>5 \mathrm{WBCs} / \mathrm{HPF}$ ) in a symptomatic patient.UTI diagnosis in asymptomatic patients particularly should be supported by a positive culture for an uropathogen [12].

It is well known that untreated UTI can be associated with serious obstetric complications to maternal and perinatal morbidity and mortality rate might be increase [13]. Untreated UTI can be associated with serious obstetric complications. The complication caused by urogenital infection and specifically by multidrug resistant microbes can cause serious problems during pregnancy [14-18] such as low birth weight and premature delivery [19]. Bacteruria, cystitis, vaginitis and pyelonephritis are the most common cause of uroginital infections $[20,21]$ hypertension, still birth, abortion, preterm labour and thrombosis are the most cause of asymptomatic infection in pregnant women [22-24]. Pyelonephritis could cause significant maternal and fetal morbidity and mortality $[25,26]$.

Therefore urogenital infection treatment is rather important task in women in general and particularly during pregnancy however, in pregnancy treatment procedure is more challenging to insure maternal and fetal safety and to prevent resistance development of uropathogens $[27,28]$. Resistance to antibiotics has been reported globally in recent years [29,30] and chronological change of antibiotic use and antibiotic resistance to uropatogens have been documented where the most typical example is the high rate of prevalence of E. coli in urinary tract infections [29] and their susceptibility vary from different place and time [30]. Therefore, the chosen antibiotic for infection treatment in certain population should have efficacy and low resistance rates [32,33].

Isolation of pathogens associated with UTIs and determining their antibiotic sensitive pattern will potentially reduce the 
inappropriate prescription of antibiotics and resistance development. Furthermore, detection of susceptibility pattern by the uropathogens against commonly used antibiotics is one effective strategy for empirical treatment. Antibiotics usually are the first line treatment for urinary tract infections. Which drugs are prescribed and for how long depend on your health condition and the type of bacteria found in your urine.

Drugs commonly recommended for simple UTIs include: Trimethoprim/sulfamethoxazole (Bactrim, Septra, others) Fosfomycin (Monurol), Nitrofurantoin (Macrodantin, Macrobid), Cephalexin (Keflex) Ceftriaxone these drugs showed less activity in many developing countries other groups of antibiotics known as fluoroquinolones-such as ciprofloxacin (Cipro), levofloxacin (Levaquin) hcich showed high activity against UTI, isn't commonly recommended for simple UTIs, as the risks of these medicines generally outweigh the benefits for treating uncomplicated UTIs however ,in some cases, such as a complicated UTI or kidney infection they are recommended [1]. Resistance to antimicrobial agents is a major health problem that affects the whole world particularly developing countries where problem is still worse due to lack of antimicrobial resistance surveys and control prescribing policies is absent. This has been reported to cause serious issue where drug prescribing policy is not controlled and random antibiotic treatment is routine matter which led to developed multidrug resistant bacteria (MDR) making treatment a difficult task and therefore increase threat to both mother and fetus and will minimize chance of prescribing safe antibiotic, treatment successes hard to achieve and infection difficult to eliminate [17,34-36].

The demographic situation plays an important role in gram positive and gram negative MDR development where increase rate of gram negative MDR increased and gram positive MDR suppose to be dominant [37]. In both cases increase rate of MDR development will enhance the possibility of formation of modified MDR strains [38,39] particularly in underdeveloped countries $[21,40]$. In conclusion susceptibility patterns of the urogenital isolates suggest the necessity of sensitivity reports before initiation of antibiotic therapy in patient suffering from infection particularly pregnant women. Further, the data obtained will help to formulate antibiotic prescription policies for treating pregnant women. This formula will reduce resistance to antibiotics used and will lay out decent monitoring systems based on the routine testing of antimicrobial sensitivity. Education policy for healthcare workers, pharmacists and health associates should be applied to reduce risks factors link to the problem.

\section{References}

1. Urinary tract infection (UTI) - Symptoms and causes - Mayo Clinic.

2. Battikhi MN, Battikhi QG (2015) Prevalence and Drug Susceptibility of Microorganism Isolated from Urinary and Genital Tracts of Pregnant Women in Jordan. EC Microbiology 2(2): 269-277.
3. Matuszkiewicz-Rowińska J, Małyszko J, Wieliczko M (2015) Urinary tract infections in pregnancy: old and new unresolved diagnostic and therapeutic problems. Arch Med Sci 11(1): 67-77.

4. Ayoade E, Moro DD, Ebene OL (2013) Prevalence and antimicrobial susceptibility pattern of asymptomatic urinary tract infections of bacterial and parasitic origins among the University students in redemption camp, Ogun state, Nigeria. OJMM 3(4): 219-222.

5. Okonko IO, Ijandipe IA, Ilusanya AO, Donbraye-Emmanuel OB, Ejembi I, et al. (2010) Detection of Urinary tract infections (UTI) among pregnant women in Olyoro Catholic hospital, Ibadan, South-western Nigeria. Malaysian Journal of Microbiology 6(1): 16-24.

6. Van Hoek AH, Mevius D, Guerra B, Mullany P, Roberts AP, et al. (2011) Acquired antibiotic resistance genes: an overview. Front Microbiol 2: 203.

7. Aiyegoro OA, Igbinosa OO, Ogunmwonyi IN, Odjadjare EE, Igbinosa OE, et al. (2007) Incidence of urinary tract infections (UTI) among children and adolescents in Ile-Ife, Nigeria. African Journal of Microbiology Research 1: 13-19.

8. Macejko AM, Schaeffer AJ (2007) Asymptomatic bacteriuria and symptomatic urinary tract infections during pregnancy. Urol Clin North Am 34(1): 35-42.

9. Hummers Pradier E, Kochen MM (2002) Urinary tract infections in adult general practice patients. Br J Gen Pract 52(482): 752-761.

10. McLaughlin SP, Carson CC (2004) Urinary tract infections in women. Med Clin North Am 88(2): 417-429.

11. Vasudevan R (2014) Urinary tract infection: an overview of the infection and the associated risk factors. J Microbiol Exp 1(2): 1-15.

12. Emilie KJ, DK Edward FACS (2011) UTIs in pregnancy. Int J Antimicrobial agents p. 85-90.

13. Gilbert NM, O'Brien VP, Hultgren S, Macones G, Lewis WG, et al. (2013) Urinary tract infection as a preventable cause of pregnancy complications: opportunities, challenges and a global call to action. Glob Adv Health Med 2(5): 59-69.

14. Matuszkiewicz-Rowińska J, Małyszko J, Wieliczko M (2015) Urinary tract infections in pregnancy: old and new unresolved diagnostic and therapeutic problems. Arch Med Sci 11(1): 67-77.

15. Gilstrap LC, Ramin SM Urinary tract infections during pregnancy. Obstet Gynecol Clin North Am 28(3): 581-591.

16. Akerele J, Abhulimen P, Okonofua F (2001) Prevalence of asymptomatic bacteriuria among pregnant women in Benin City Nigeria. J Obstet Gynaecol 21(2): 141-144.

17. Nwadike SOA, Okorondu SI, Obiajuru IOC, Nwadike PO, Nwaokorie FO, et al. (2015) Comparative study of the prevalence and antibiogram of bacterial isolates from the urinary and genital tracts of antenatal patients. IOSR Journal of Pharmacy and Biological Science 10(1): 15-19.

18. Lee M, Bozzo P, Einarson A, Koren G (2008) Urinary tract infections in pregnancy. Canadian Family Physician 54(6): 853-854. 
19. Demilie T, Beyene G, Melaku S, Tsegaye W (2014) Diagnostic accuracy of rapid urine dipstick test to predict urinary tract infection among pregnant women in Felege Hiwot Referral Hospital, Bahir Dar, North West Ethiopia. BMC Res Notes 7: 481.

20. Anyadoh-Nwadike SO, Okorondu SI, Obiajuru IOC, Nwadike PO, Nwaokorie FO, et al. (2015) Comparative study of the prevalence and antibiogram of bacterial isolates from the urinary and genital tracts of antenatal patients. IOSR Journal of Pharmacy and Biological Science 10(1): 15-19.

21. Onuh SO (2006) Microbiological isolates and sensitivity pattern of urinary tract infection in pregnancy in Benin City, Nigeria. Ebonyi Medical Journal 5(2): 48-52.

22. Anyadoh SO (2010) Prevalence of multidrug resistant Escherichia coli among pregnant women in Owerri. International Journal of Medical Sciences and Technology 3(3): 17-20.

23. Zinner SH (1992) Management of urinary tract infection in pregnancy; A review with comments on single dose therapy. Journal of Infection 20: S280.

24. Akerele J, Abhulimen P, Okonofua F (2002) Prevalence of asymptomatic genital infection among pregnant women in Benin-city, Nigeria. Afr J Reprod Health 6(3): 93-97.

25. Akerele J, Abhulimen P, Okonofua F (2001) Prevalence of asymptomatic bacteriuria among pregnant women in Benin City Nigeria. J Obstet Gynaecol 21(1): 141-144.

26. Lucas MJ, Cunningham FG (1994) Urinary tract infection complicating pregnancy. In Williams Obstetrics. $19^{\text {th }}$ edn, McGraw Hill, New York, USA, p: 1-15.

27. Mitchell AA, Gilboa SM, Werler MM, Kelley KE, Louik C, et al. (2011) Medication use during pregnancy, with particular focus on prescription drugs: 1976-2008. Am J Obstet Gynecol 205(1): 51.e1-51.e8.

28. Kladensky J (2012) Urinary tract infections in pregnancy: when to treat, how to treat, and what to treat with. Ceska Gynekol 77(2): 167171.

29. Shigemura K, Tanaka K, Adachi M, Yamshita M, Arakawa S, et al. (2011) Chronological change of antibiotic use and antibiotic resistance in
Escherichia coli causing urinary tract infections. J Infect Chemother 17(5): 646-651.

30. Gupta K, Hooton TM, Stamm WE (2001) Increasing antimicrobial resistance and the management of uncomplicated community acquired urinary tract infections. Ann Intern Med 135(1): 41-50.

31. Sefton AM (2000) The impact of resistance on the management of urinary tract infections. Int J Antimicrob Agents 16(4): 489-491.

32. Okonko IO, Ijandipe IA, Ilusanya AO, Donbraye Emmanuel OB, et al. (2010) Detection of Urinary tract infections (UTI) among pregnant women in Olyoro Catholic hospital, Ibadan, South-western Nigeria. Malaysian J Microbiology 6(1): 16-24.

33. Clani O, Grassi D, Tarriconi R (2013) An economic perspective on UTI: the costs of resignation. Clin Drug Investig 33(4): 255-261.

34. Uneke C, Alo M (2007) Nongonococcal and nonchlamydial microbial isolates from high vaginal swabs of Nigerian women diagnosed with pelvic inflammatory disease. The Internet Journal of Infectious Diseases 6(1): 1 -6.

35. Melvin DG (1990) Optimum therapy for acute pelvic inflammatory disease. Drugs 39(4): 511- 522.

36. Nworie A, Eze UA (2010) Prevalence and aetiologic agents of urinary tract infection in pregnancy in abakaliki metropolis. Continental Journal of Medical Research 4: 18 -23.

37. Connolly A, Throp JM Jr (1999) Urinary tract infections in pregnancy. Urol Clin North Am 26(4): 779-787.

38. Battikhi MN, Battikhi Q (2015) Correlation of Urinary Tract Infection Pathogens, Antibiogram and Age Group in Pregnant Women. JMEN 2(4): 1-6.

39. Unlu BS, Yildiz Y, Keles I, Kaba M, Kara H, et al. (2014) Urinary tract infection in pregnant population, which empirical antimicrobial agent should be specified in each of the three trimesters? Gineko Pol 85(5): 371-376.

40. Russel AD (1994) Types of antibiotics and synthetic antimicrobial agents. In: Hugo WB, AD Russell (Eds.) Pharmaceutical Microbiology. ( ${ }^{\text {th }}$ edn), Blackwell Scientific Publications, London, pp: 99-133.

\section{Your next submission with Juniper Publishers will reach you the below assets}

- Quality Editorial service

- Swift Peer Review

- Reprints availability

- E-prints Service

- Manuscript Podcast for convenient understanding

- Global attainment for your research

- Manuscript accessibility in different formats

( Pdf, E-pub, Full Text, Audio)

- Unceasing customer service

Track the below URL for one-step submission https://juniperpublishers.com/online-submission.php 